\title{
MEASUREMENT OF TECHNICAL EFFICIENCY USING THE DEA AND SFA METHODS: A CASE STUDY ON MALAYSIAN TRANSPORT MANUFACTURING INDUSTRY
}

\author{
NORAYATI HASHIM ${ }^{1}$, AMMAR-FIKREE MOHAMED JOFREE ${ }^{1}$, MOHD FAHMY- \\ ABDULLAH $^{1,2 *}$ AND LAI WEI SIENG ${ }^{3}$
}

${ }^{1}$ Faculty of Technology Management and Business, Universiti Tun Hussien Onn Malaysia, Malaysia, 86400 Parit Raja, Batu Pahat, Johor, Malaysia. ${ }^{2}$ OASIS Integrated Group, Institute for Integrated Engineering, Universiti Tun Hussein Onn Malaysia, 86400 Parit Raja, Batu Pahat, Johor, Malaysia. ${ }^{3}$ Faculty of Economics and Management, Universiti Kebangsaan Malaysia, 43600 UKM Bangi, Selangor, Malaysia.

*Corresponding author: mohdfahmy@uthm.edu.my

Submitted final draft: 4 July 2021

Accepted: 14 August 2021

http://doi.org/10.46754/jbsd.2021.09.004

\begin{abstract}
At present, there is limited research on the state of the transport manufacturing industry in Malaysia. This article presents an analysis on the technical efficiency (TE) of the Malaysian transport manufacturing industry using the established parametric and non-parametric approaches of Data Envelopment Analysis (DEA) and Stochastic Frontier Analysis (SFA), respectively based on Department of Statistics Malaysia (DoSM) data of 611 firms between 2005 and 2010. The results showed that within the DEA approach, the Variable Return to Scale (VRS) model gave higher average efficiency than the Constant Return to Scale (CRS) model, whereas the Translog function was found to be superior to the Cobb-Douglas function in the SFA approach. Overall, high efficiency values were found in both the parametric and non-parametric methods and the results were consistent. Spearman's coefficients showed weak correlations between the DEA and SFA approaches, with inconsistencies among the samples. Limited comparisons, however, could be made based on subsectors. Although inconsistencies were found in both approaches to identify firms with best and worst performances, the methods could still be useful in measuring TE through a careful selection of the input and output variables, depending on the context, objectives, and environment of the measurement.
\end{abstract}

Keywords: Technical efficiency, data envelopment analysis, stochastic frontier analysis.

\section{Introduction}

In recent years, the rapid development of the global transport industry has led to an increase in research on the level of efficiency in the transport and logistics industry. Examples include the works of Jarboui et al. (2013), Chang and Tovar (2014), Gonzalez (2015), Rhee and Kim (2015), and Fahmy-Abdullah et al. (2019).

Despite being one of the main industries in Malaysia, there has been limited research done on the technical efficiency (TE) of the Malaysian transport industry. Existing studies are nonexhaustive and generally involve whole subindustries. Moreover, conflicting results from the various approaches used in the studies could confuse policymakers in the transport industry and make it difficult for them to decide on the best courses of action to be taken to improve the industry's TE. TE is widely used as an indicator to gauge the efficiency level of a company or an industry (Mahadevan, 2004) and it has been used successfully to measure said levels in various organisations and industries (Cullinane et al., 2006). In general, approaches to measuring TE can be classified into two, namely, parametric, and non-parametric (Jarboui et al., 2012).

An example of a parametric approach is the Stochastic Frontier Analysis (SFA), which evaluates the cost, profit, or production functions based on the input, output, and environmental parameters (Aigner et al., 1977). In the estimation, the effects of random errors and inefficiencies are considered immaterial 
to these parameters (Boame, 2004). As SFA considers the problem structure and evaluates the performance determinants and factors (Cullinane et al., 2006; Fahmy-Abdullah et al., 2019, Latif et al., 2019), the method is flexible and suitable for use in the hypothesis-testing of parameters in economic theories (Coelli, 1996; Coelli et al., 2005).

On the other hand, a non-parametric approach such as the Data Envelopment Analysis (DEA) method (Farrell, 1957) estimates the input-output relationship in a given problem with minimal assumptions (Banker et al., 1984). DEA can be used to evaluate the efficiency of an organisation, or a Decision-Making Unit (DMU) as it is known in the DEA literature, that is sensitive to unreliable data. An efficient DMU forms an efficiency boundary for units within the boundary (Avkiran, 2001). DEA ignores the effects of random errors in the hypothesistesting, and the efficiency estimates are not based on statistics (Boame, 2004).

There is an ongoing debate on which are of the approaches is superior to measure TE and the use of both approaches is widely reported in the literature. Examples of DEA applications can be found in Yu and Fan (2009), Agarwal et al. (2010), Sun et al. (2015) and Sabli et al. (2019), while works on SFA include Coto-Millan et al. (2004), Mazumder and Adhikary (2010), Jarboui et al. (2015) and Fahmy-Abdullah et al. (2017), among others.

A summary of studies comparing both approaches to measure TE in various industries was given by Lovell (1993). Ferrier and Lovell (1990) and Cullinane et al. (2006) compared the performance of the two approaches to measure cost efficiency in banking applications and portrelated efficiency, respectively. Other similar comparison studies can be found in Karlaftis and Tsamboulas (2012), Odeck and Braten (2012), Randrianarisoa et al. (2015), Coelli and Perelman (1999) and Lin et al. (2013). The last two works focused on the comparison between the three approaches.

To the best of the author's knowledge, there is no previous work on the comparison between different approaches to measuring efficiency in the Malaysian transport industry. This article presents a comprehensive analysis of the measurement of TE level of the Malaysian transport industry using the DEA and SFA methods. It is hoped that the comparative analysis would enable the evaluation of the suitable conditions in which each approach could be employed when measuring TE. Such results would be beneficial for stakeholders and policymakers and of the Malaysian transport industry to devise better action plans and recommendations to improve the industry.

\section{Data and Methodology}

\section{Data Envelopment Analysis (DEA)}

The DEA method is a non-parametric approach to measure the efficiency of a DMU based on the linear programming method (Farrell, 1957). Since its development, several improvements have been proposed to the original model. Follow-up studies by Charnes et al. (1978) and Coelli (1996) led to the development of an inputbased model known as the Charnes, Cooper, and Rhodes (CCR) model. A major feature in this model was the assumption of a constant rate reduction and increase in the input and output, respectively, for each DMU.

Thus, the method is also known as the CCRconstant return to scale (CRS), or the CCR-CRS model, which can be used to compute General Technical Efficiency (GTE) scores (Nunamaker, 1985). The CCR-CRS model formulation can be written as:

subject to:

$$
\begin{aligned}
& \min l_{\mathrm{o}}^{*}-\varepsilon\left(\sum_{i=1}^{M \prime} S_{i}^{-}+\sum_{r=1}^{s} S_{r}^{+}\right) \\
& \sum_{=1}^{N} \lambda_{f} x_{i f}=l_{0} \mathrm{x}_{i f o}-S_{i}^{-} \quad \text { where } i=1 \ldots m
\end{aligned}
$$

$$
\begin{aligned}
& \sum_{j=1}^{N} \lambda_{f} y_{r f}=S_{r}^{+}-\mathrm{y}_{r f o} \quad \text { where } r=1 \ldots s \\
& \lambda_{f} \geq 0, f=1 \ldots N, S_{i}^{-}, S_{r}^{+} \geq 0 \mathrm{v} i \text { and }
\end{aligned}
$$


Note: In Equation (1), $x_{i f}$ and $y_{r f}$ are the th input and $r$ th output levels, respectively for $\mathrm{DMU} f ; \mathrm{N}$ is the total DMUs; $\varepsilon$ is a very small, non-Archimedean positive number as lower bound to inputs and outputs; $\lambda_{f}$ is DMU $f$ contribution in the efficiency of rated DMU $f_{o}$, at a point on the envelopment surface; $S_{T}^{+}$ and $S_{T}^{-}$are slack variables to represent the extra savings and gains in input $i$ and output $r$, respectively; $l_{\mathrm{o}}$ is the radial efficiency factor indicating the possible reduction of inputs for $\operatorname{DMU} f_{o}$. If $l_{\mathrm{o}}{ }^{*}$ (optimal solution) $=1$, and $S_{T}^{+}=$ $S_{T}^{-}=0$, then DMU $f_{o}$ can be taken as efficient. If $S_{T}^{+}>0$ and $S_{T}^{+}>0$ at the optimal solution, the corresponding DMU $f_{o}$ input and output can be improved further when the input levels contract to the proportion of $l_{\mathrm{o}}^{*}$.

In the CCR model, the CRS assumption in calculating efficiency leads to the assumption that efficiency and DMU operating size are not significantly related. The CRS assumption, however, is only valid for a DMU that is operating at its optimum level. Since rise and fall in the economies of scale (SE) (minimal inputs causing maximum outputs) are foreseeable among the companies in the transport industry, the optimum level assumption may be invalid, leading to an inaccurate TE score.

The BCC model by Banker, Charnes, and Cooper (1984) attempted to improve the CCRCRS model by introducing the Variable Return to Scale (VRS) to estimate a Local Pure Technical Efficiency (LPTE) score (Nunamaker, 1985). The VRS assumption enables TE calculation without SE. Once the TE score for a DMU is calculated, the value is compared to the LPTE score. The difference between the two values indicates that the scale inefficiency, as TE $=\mathrm{PTE}$ $x$ SE.

This implies that the firm can use the resources to exploit the SE on the border of production in the CRS case. The BCC-VRS formulation can be written as:

$$
\begin{aligned}
& \min _{N} l_{\mathrm{o}}^{*}-\varepsilon\left(\sum_{i=1}^{m} S_{i}^{-*}+\sum_{i=1}^{s} S_{r}^{+*}\right) \\
& \sum_{\sum_{1}}^{N} \lambda_{f} x_{i f}=l_{0} \mathrm{x}_{i f o}-S_{i}^{-*} \quad \text { where } \quad i=1 \ldots m \\
& \sum_{j=1}^{N} \lambda_{f} y_{r f}=S_{r}^{+*}-\mathrm{y}_{r f o} \quad \text { where } \quad r=1 \ldots s \\
& \lambda_{f} \geq 0, f=1 \ldots N, S_{i}^{-*}, S_{r}^{+*} \geq 0 \underline{\mathrm{V} i} \text { and } r
\end{aligned}
$$

Note, that the inclusion of the convexity constraint, $\lambda_{f}=1$ in the BCC-VRS model prevents the scaling up or down of any interpolation point from the observed DMU, which can turn it into a reference point. The values of $\lambda$ minimise $l_{\text {o }}$ to $l_{\circ}^{*}$ to identify a point, of which the lowest proportion of $l_{\mathrm{o}}^{*}$ is reflected by the input levels. At $l_{\mathrm{o}}{ }^{*}$, the DMU $f_{o}$ input levels can uniformly contract without affecting the output. Thus, DMU $f_{o}$ has an efficiency equals to $l_{\mathrm{o}}^{*}$. The solution to Equation (2) can be written as: DMU $f_{o}$ is Pareto-efficient if $l_{\mathrm{o}}^{*}=1$ and $=S_{T}^{+}=0, r=$ $1 \ldots s, S_{T}^{-}=0$, for $i=1 \ldots m$.

\section{Stochastic Frontier Analysis (SFA)}

The SFA model originally developed by Aigner et al. (1977) was further revised by Meeusen et al. (1977) and later Battese and Coelli (1995) to measure TE scores. In this article, the SFA model based on the Cobb-Douglas and Translog functions (Coelli et al., 2005) that consists of three inputs and a single output are applied. The Cobb-Douglas and Translog functions are given in Equation (3) and Equation (4), respectively, as:

$\ln Y_{i}=\hat{a}_{0}+\hat{a}_{1} \ln \mathrm{K}_{i}+\hat{a}_{2} \ln \mathrm{L}_{i}+\hat{a}_{3} \ln \mathrm{AV}_{i}\left(\mathrm{v}_{i}-\mathrm{u}_{i}\right)$

$\ln Y_{i}=\hat{a}_{0}+\hat{a}_{1} \ln \mathrm{K}_{i}+\hat{a}_{2} \ln \mathrm{L}_{i}+\hat{a}_{3} \ln \mathrm{AV}_{i} \hat{a}_{4}\left(\ln \mathrm{K}_{i}\right)^{2}$

$+\hat{a}_{5}(\operatorname{lnL})^{2}+\hat{a}_{6}\left(\ln \mathrm{AV}_{i}\right)^{2}+\hat{a}_{7}\left(\ln \mathrm{K}_{i} \mathrm{x} \ln \mathrm{L}_{i}\right)$

$+\hat{a}_{8}\left(\ln \mathrm{K}_{i} \times \ln \mathrm{AV}_{i}\right)+\hat{a}_{8}\left(\ln \mathrm{L}_{i} \mathrm{x} \ln \mathrm{AV}_{i}\right)+\left(\mathrm{v}_{i}-\mathrm{u}_{i}\right)$ 
where $Y_{i}$ is the $\log$ of the $i$-th firm nominal output amount; $\mathrm{K}_{i}$ is the $\log$ of the $\mathrm{i}$-th firm nominal asset amount; $\mathrm{L}_{i}$ is the $\log$ of the $\mathrm{i}$-th firm labor amount; $\mathrm{AV}_{i}$ the log of the $i$-th firm added value amount; $\mathrm{v}_{i}$ is the random variable or effect, independent and identically distributed (i.i.d), with $\left[\mathrm{N}\left(0, \mathrm{o}_{\mathrm{v}}^{2}\right)\right] ; \mathrm{u}_{i}$ is an assumed nonnegative random variable to reflect inefficiency in production that is normally taken as i.i.d. and truncated at zero for distribution $\left[N\left(\mathrm{~m}_{i}, \mathrm{o}_{\mathrm{u}}{ }^{2}\right)\right]$.

\section{Specifications of the Firms' Input and Output Variables}

Tingley et al. (2005) stated that the use of firm-level data in budgeting is desirable as more accurate analysis can be performed on the factors that affect the budgeting process. Battese and Coelli (1995) showed that using firm-level data enabled the determinant factors to be considered more accurately, leading to more accurate estimations of the efficiency level. However, collecting firm-level data is challenging due to issues on confidentiality and time constraint. This often resulted in the lack of responses from the employers in surveys, including those conducted at the national level such as by the DoSM. Thus, previous related studies on the transport industry such as by Putri (2007), Rahmah and Idris (2008) and Noor Aini (2013) were based on industry-level data.

This study used the firm-level data from the DOSM Annual Survey of Manufacturing Industries between 2005 and 2010, which is the latest available data based on the Economic Census 2015. The input, output, and other study variables were carefully selected based on the current objectives and previous studies. Following the approach in Mankiw et al. (1995), three inputs were used for the models, namely, capital (x1), labor (x2) and production factor (x3). Capital (in RM) represented the firm's construction and improvement expenditure for the year in terms of the purchase value and fixed assets, while the workers represented the total value paid in wages including the benefits.

The production factor was an intermediate input that represented the total value of related materials and services used, including the utilities, fuels, and others. For the output variable, the firm's total product sales (y1) was selected. A summary of the input and output variables and their descriptive statistics are shown in Table 1.

Table 1: Summary of the input and output variables

\begin{tabular}{ccccc}
\hline Output & Mean & Minimum & Maximum & Standard Deviation \\
\hline Sales (y1) & 4176086 & 275896 & 21318011 & 4589477.059 \\
Input & & & & \\
Capital (x1) & 942623 & 57964 & 4465787 & 919913.636 \\
Labor (x2) & 8508 & 894 & 22477 & 6679.767 \\
Production Factor (x3) & 4058439 & 201730 & 18044586 & 3944969.305 \\
\hline
\end{tabular}

Source: Department of Statistics Malaysia (DOSM), 2005 to 2010

Based on Malaysia Standard Industrial Classifications (MSIC) for the years 2000 and 2008, the DOSM data was classified into six sub-industries at the three-digit level, according to the types of transport constructions. The six categories were for the manufacturing of

1) Motor vehicle, passenger car, and commercial vehicle,

2) Frames for motor vehicles, trailers, and semi-trailers,
3) Motor vehicles accessories and spare parts,

4) Ships and boats, floating structures, cruise, and sports boats,

5) Aircraft, spacecraft, and related machinery, and

6) Transport equipment with activities that are not elsewhere classified (n.e.c.), motorcycles, bicycles, and vehicles for persons with disabilities. 
The selection of the DoSM data was performed at random, following a step-bystep identification and screening of the firms based on the size of the firms (large, medium, or small), employees count, capital, and the value added. During the screening, firms with incomplete information (missing values) and those that did not meet the small and medium company definition (number of employees less than five) were discarded as these would affect the subsequent analysis. The final selection resulted in a total of 611 firms, from which the input and output data in the year 2005 were taken for use in the analysis.

To determine the consistencies of the results and whether the study objectives were achieved, the efficiency results were compared based on the five criteria as stated in Bauer et al. (1998), namely, efficiency distribution in each model, efficiency ranking, and identification of the worst and best performances among the firms.

\section{Results and Discussions}

\section{Efficiency Values: DEA Model}

The CCR-CRS and the BCC-VRS models were used to calculate efficiency scores of the six Malaysian transport manufacturing industry subsectors for the year 2005 until 2010. All calculations were performed using the DEAP Software, version 2.1 (Coelli, 1996). The calculated efficiency scores are tabulated in Table 2.

Table 2: Efficiency scores calculated using the CCR-CRS and BCC-VRS models for the year 2005 until 2010

\begin{tabular}{ccccccc}
\hline & \multicolumn{5}{c}{ CCR-CRS Model } \\
\cline { 2 - 7 } & 2005 & 2006 & 2007 & 2008 & 2009 & 2010 \\
\hline 1 & 0.201 & 0.287 & 0.437 & 0.482 & 0.446 & 0.184 \\
3 & 0.211 & 0.490 & 0.373 & 0.258 & 0.379 & 0.172 \\
4 & 0.281 & 0.426 & 0.396 & 0.343 & 0.347 & 0.250 \\
5 & 0.274 & 0.327 & 0.381 & 0.312 & 0.310 & 0.172 \\
6 & 0.345 & 0.464 & 0.270 & 0.340 & 0.152 & 0.225 \\
\hline Average & 0.282 & 0.383 & 0.331 & 0.447 & 0.327 & 0.279 \\
\hline & 0.266 & 0.396 & 0.364 & 0.363 & 0.347 & 0.213 \\
\hline 1 & & & BCC-VRS Model & & \\
\hline 2 & 0.348 & 0.541 & 0.616 & 0.724 & 0.594 & 0.389 \\
3 & 0.480 & 0.536 & 0.497 & 0.398 & 0.475 & 0.440 \\
4 & 0.405 & 0.535 & 0.568 & 0.559 & 0.585 & 0.503 \\
5 & 0.480 & 0.525 & 0.610 & 0.575 & 0.615 & 0.411 \\
6 & 0.442 & 0.542 & 0.535 & 0.520 & 0.391 & 0.394 \\
\hline Average & 0.504 & 0.574 & 0.651 & 0.675 & 0.705 & 0.557 \\
\hline
\end{tabular}

Note: Subsector 1) motor vehicle, passenger car, and commercial vehicle, 2) frames for motor vehicles, trailers, and semi-trailers, 3) motor vehicles accessories and spare parts, 4) ships and boats, floating structures, cruise, and sports boats, 5) aircraft, spacecraft, and related machinery, and 6) transport equipment with activities that are not elsewhere classified (n.e.c.), motorcycles, bicycles, and vehicles for persons with disabilities 
The results showed that the BCC-VRS model gave a higher average efficiency at 0.525 , compared to the CCR-CRS at 0.325. This was expected as the BCC-VRS model calculated the LPTE without the use of SE and thus it was not limited to the assumption on constant input reduction and output increase as formulated in the CCR-CRS model. Results from the BCCVRS model showed that the highest annual average efficiency score was in 2007 at 0.579 , while the best-performing subsector within the period was subsector 6 , with an average efficiency score of 0.611 . For this study, the BCC-VRS model was selected for comparison with the SFA approach.

\section{Efficiency Values: SFA Model}

To compare the Cobb-Douglas and the Translog functions in the SFA model, the following hypothesis test was performed using the likelihood-ratio test, $\operatorname{LR}(\lambda)$. The following null hypotheses were proposed:

$\mathrm{H}_{0}=$ The Cobb-Douglas production function is suitable for data representation in this study

$\mathrm{H}_{1}=$ The Translog production function is suitable for data representation in this study
The LR test ${ }^{1}\left(H_{0}: \beta_{i j}=0\right)$ was performed and the results were compared against the critical value for $\chi_{6}^{2}$ distribution at a $5 \%$ significance level, as shown in Table 3.

Table 3: Hypothesis tests results for the CobbDouglas and Translog functions

\begin{tabular}{lc}
\hline Null Hypothesis & Cobb-Douglas \\
& $\left(H_{0}: \beta_{i j}=0\right)$ \\
& $36.09^{* * *}$ \\
LR Statistics & $\mathbf{1 6 . 8 1 * * *}$ \\
Critical Value & Reject $\mathrm{H}_{\mathrm{o}}$ \\
Result & \\
\hline
\end{tabular}

Note: *** shows $1 \%$ significance level

Based on the results, the null hypothesis $\mathrm{H}_{0}$ was rejected and the Translog function was selected for further analysis. Efficiency scores were calculated using the Translog function for the same input and output data used for the DEA model calculation previously and the results are shown in Table 4.

Table 4: Efficiency scores calculated using SFA model (Translog function) for the year 2005 until 2010

\begin{tabular}{ccccccc}
\hline & \multicolumn{7}{c}{ SFA Model (Translog Function) } \\
\cline { 2 - 7 } & 2005 & 2006 & 2007 & 2008 & 2009 & 2010 \\
\hline 1 & 0.584 & 0.657 & 0.939 & 0.688 & 0.751 & 0.718 \\
2 & 0.494 & 0.580 & 0.717 & 0.767 & 0.536 & 0.468 \\
3 & 0.521 & 0.624 & 0.780 & 0.577 & 0.744 & 0.633 \\
4 & 0.467 & 0.672 & 0.578 & 0.609 & 0.610 & 0.498 \\
5 & 0.509 & 0.491 & 0.951 & 0.442 & 0.522 & 0.435 \\
6 & 0.573 & 0.595 & 0.712 & 0.629 & 0.547 & 0.747 \\
\hline Average & 0.525 & 0.603 & 0.780 & 0.619 & 0.618 & 0.573 \\
\hline
\end{tabular}

Note: Subsector 1) motor vehicle, passenger car, and commercial vehicle, 2) frames for motor vehicles, trailers, and semi-trailers, 3) motor vehicles accessories and spare parts, 4) ships and boats, floating structures, cruise, and sports boats, 5) aircraft, spacecraft, and related machinery, and 6) transport equipment with activities that are not elsewhere classified (n.e.c.), motorcycles, bicycles, and vehicles for persons with disabilities

1 LR test statistic, $L=-2\left\{\ln \left[L\left(H_{0}\right) / L\left(H_{I}\right)\right]\right\}=-2\left\{\ln \left[L\left(H_{0}\right)\right]\right.$ has q2 distribution, where q is the number of parameters, assumed zero in a null hypothesis. 
The average efficiency scores showed that all subsectors operated at moderate efficiency levels. The lowest and highest annual efficiency scores were at 0.53 and 0.78 in 2005 and 2007, respectively. The highest average efficiency among the subsectors for the period was found in subsector 1 at 0.723 , and the lowest in subsector 5 , at 0.558 .

\section{Comparison of DEA and SFA Models Results}

To perform a comprehensive comparison between the models, the results were compared in terms of the five criteria as stated in Bauer et al. (1998), namely, efficiency distribution in each model, efficiency ranking, and identification of the worst and best performances among the firms.

\section{First Criteria: Efficiency Distributions in Each Model}

Table 5 shows a comparison of the efficiency values calculated using the two models for three sets of samples, namely, based on the subsector, year, and combined. The SFA model had a higher overall efficiency at 0.624 , compared to the DEA model at 0.529 . The mode was found to be 0.895 and 1.000 for the SFA and DEA models, respectively. The results showed that the average efficiency of the industry is at a modest level. The standard deviation found in the SFA model was lower at 0.127 , compared to 0.136 for the DEA model, indicating closer positions of the respective firm to the full efficiency level in the parametric SFA approach. The skewness values showed that the distributions in both models were close to symmetrical, with a small bias to the left as the mode was larger than the average value. Based on the kurtosis values, the results in the SFA model seemed to be more dispersed and had higher average efficiency. Overall, the transport industry level of volatility can be interpreted as mesokurtic and consistent.

Table 5: Efficiency distributions of the DEA and SFA Models

\begin{tabular}{ccccccc}
\hline & \multicolumn{3}{c}{ DEA Model } & \multicolumn{3}{c}{ SFA Model } \\
\cline { 2 - 7 } & All & Year & Subsector & All & Year & Subsector \\
\hline Mean & 0.529 & 0.538 & 0.521 & 0.624 & 0.628 & 0.621 \\
Median & 0.449 & 0.564 & 0.522 & 0.662 & 0.619 & 0.620 \\
Mode & 1.000 & - & - & 0.895 & - & - \\
Minimum & 0.103 & 0.436 & 0.471 & 0.023 & 0.522 & 0.555 \\
Maximum & 1.000 & 0.593 & 0.603 & 1.000 & 0.736 & 0.717 \\
Standard deviation & 0.293 & 0.067 & 0.048 & 0.251 & 0.070 & 0.059 \\
Skewness & 0.488 & -0.822 & 0.922 & -0.451 & 0.114 & 0.691 \\
Kurtosis & -1.138 & -1.239 & 1.120 & -0.939 & 1.382 & 0.208 \\
\hline Total number of firms & 611 & 611 & 611 & 611 & 611 & 611 \\
\hline
\end{tabular}

In summary, high efficiency values calculated by the two models, and the distribution of the results between the models were consistent. It should be noted that the good agreement between the parametric SFA model and the non-parametric DEA model was made possible through the careful filtering of the data. As non-parametric approaches are sensitive to external factors, careful considerations of these factors would enable more reliable estimations of the efficiency values.

\section{Second Criteria: Efficiency Ranking}

Although the firms' efficiency values estimated by the DEA and SFA models may differ slightly, 
the models may yield inaccurate firms' positions across the methods. For policymakers, the identification of more effective firms is more important than measuring the absolute efficiency values. An adopted policy based on inaccurate results of firms' positions will be unstable and dependent on the applied boundary approach Bauer et al. (1998).

Table 6: Spearman's rank correlation coefficients for the DEA and SFA models

\begin{tabular}{ccccccc}
\hline & \multicolumn{3}{c}{ DEA } & & \multicolumn{3}{c}{ SFA } \\
\cline { 2 - 6 } & All & Year & Subsector & All & Year & Subsector \\
\hline DEA all & 1.000 & & & & & \\
DEA year & 0.029 & 1.000 & & & & \\
DEA subsector & $0.771^{*}$ & -0.429 & 1.000 & & & \\
SFA all & -0.143 & 0.257 & 0.086 & 1.000 & & \\
SFA year & $-0.771^{*}$ & 0.429 & -0.657 & 0.257 & 1.000 & \\
SFA subsector & 0.429 & -0.714 & $0.771^{*}$ & -0.371 & -0.429 & 1.000 \\
\hline
\end{tabular}

Note: * shows $10 \%$ significance level based on the Spearman's rank correlation coefficient table

Table 6 shows the calculated SFA and DEA models Spearman's rank correlation coefficients for different samples, namely, based subsector, year, and combined. For the SFA, the correlation between the subsectors' sample and the whole sample was -0.371 . On the other hand, the same case in the DEA model gave a positive and significant value of 0.771 .

Overall, weak and inconsistent correlations were found between the SFA and DEA results. As shown in Table 4, out of the nine values, four were negative, with one of them being significant. However, the DEA subsector and SFA subsector results had a positive and significant correlation, at 0.771 . The findings indicated that results using both models would be comparable if the input data were based on the subsector samples. Using other samples would lead to contradictory results due to the different firms' positions and could cause uncertainty for policymakers attempting to use the results for any decision-making.

\section{Third Criteria: Identification of the Worst and Best Performances among the Firms}

In cases where the firms' positions are different, consistent efficiency results could be calculated by identifying the worst and best performances among the firms. Table 7 shows the results of the DEA and SFA models.

Table 7: The worst and best performances among the firms as calculated by the DEA and SFA models

\begin{tabular}{ccccccc}
\hline & \multicolumn{3}{c}{ DEA } & & \multicolumn{2}{c}{ SFA } \\
\cline { 2 - 6 } & All & Year & Subsector & All & Year & Subsector \\
\hline DEA all & & 0.089 & $-0.213 * * *$ & $0.744 * * *$ & -0.039 & $-0.156^{* *}$ \\
DEA year & $0.370 * * *$ & & -0.009 & $0.199 * * *$ & $0.599 * * *$ & -0.032 \\
DEA subsector & $0.332 * * *$ & $0.359 * * *$ & & -0.096 & $-0.247 * * *$ & $0.667 * * *$ \\
SFA all & $0.999 * * *$ & $0.371^{* * *}$ & $0.331 * * *$ & & -0.114 & $0.185 * *$ \\
SFA year & $0.212 * * *$ & $0.935^{* * *}$ & $0.305 * * *$ & $0.213 * * *$ & & $-0.310^{* * *}$ \\
SFA subsector & 0.022 & $0.215^{* * *}$ & $0.865 * * *$ & 0.021 & $0.228 * * *$ & \\
\hline
\end{tabular}

Note: The upper-right triangle values indicate the top $25 \%$ performance while the lower-left triangle values indicate the bottom $25 \%$; *** shows $1 \%$ significance level; ** shows $5 \%$ significance level 
In Table 7, values above the diagonal line were based on samples comprising the top $25 \%$ of the firms. For instance, the results showed that $74.4 \%$ of the firms in the SFA all sample, which were the top $25 \%$ of all firms (153 firms from a total of 611), were also identified in the DEA all sample.

This value was at a $1 \%$ significance level. Similarly, values below the diagonal line of Table 7 represented the bottom $25 \%$ of the firms. Generally, the results showed a poor consistency between the results from the two approaches. In the parametric SFA model, only one positive value was recorded in the best-performing firms, which was $18.5 \%$, at a $5 \%$ significance level. For the worst-performing samples, two out of three samples were positive with an average value of $22.05 \%$, at a $1 \%$ significance level. For the non-parametric DEA model, results for the bestperforming firms showed inconsistencies. On the other hand, all results for the worst-performing firms were consistent with an average value of $35.4 \%$ at a $1 \%$ significance level.

Comparison between the DEA and SFA samples for the best-performing firms showed a poor consistency, with four of the nine samples showing positive values at a $1 \%$ significance level and an average of $51.4 \%$. The other five samples were negative, of which two were significant. The comparison between the worstperforming firms, however, showed better agreement with eight positive values at a $1 \%$ significance level and $52.91 \%$ average value.

\section{Conclusion}

This study compared the TE values calculated using two approaches, namely, the parametric SFA approach and the non-parametric DEA approach. Firm-level data from the DOSM Annual Manufacturing Industries Survey for the year 2005 to 2010 was applied. It was found that the average efficiency values calculated by the two approaches were at a high degree and the distributions of results in both approaches were consistent.
The results of Spearman's coefficients between the DEA and SFA results showed weak and inconsistent correlations between the two. Based on the results, the DEA method can be applied by policymakers to measure the TE of firms, while the SFA method is more suitable to identify inefficiency factors.

\section{Acknowledgements}

The authors would like to thank the Department of Statistic Malaysia (DOSM) for their permission on the data use, and the Higher Education Ministry (MoHE), Universiti Tun Hussein Onn Malaysia (UTHM), and Universiti Kebangsaan Malaysia (UKM) for providing support in funding and facilities. This work was performed under the grant UTHM-GPPS-H449-2019 with support of the UTHM Registrar and Research Management Centre.

\section{References}

Agarwal, S., Yadav, S. P., \& Singh, S. P. (2010). DEA based estimation of the technical efficiency of state transport undertakings in India. Opsearch, 47(3), 216-230.

Aigner, D., Lovell, C. K., \& Schmidt, P. (1977). Formulation and estimation of stochastic frontier production function models. Journal of Econometrics, 6(1), 21-37.

Avkiran, N.K.(2001). Investigating technical and scale efficiencies of Australian universities through data envelopment analysis. Socioeconomic Planning Sciences, 35(1), 57-80.

Banker, R. D., Charnes, A., \& Cooper, W. W. (1984). Some models for estimating technical and scale inefficiencies in data envelopment analysis. Management Science, 30(9), 1078-1092.

Banker, R. D., \& Morey, R. C. (1986). Efficiency analysis for exogenously fixed inputs and outputs. Operations Research, 34(4), 513521.

Basri, Abdul Hamid \& Tan Y.L. (2006). "Kajian Sosio-Ekonomi dan Kecekapan 
Teknikal Penangkapan Ikan Nelayan di Negeri Melaka." Persidangan Pertama Pembangunan Komuniti Pulau dan Pesisir Pantai, KUSTEM. 106-125.

Battese, G. E., \& Coelli, T. J. (1988). Prediction of firm-level technical efficiencies with a generalized frontier production function and panel data. Journal of Econometrics, 38(3), 387-399.

Battese, G. E., \& Coelli, T. J. (1995). A model for technical inefficiency effects in a stochastic frontier production function for panel data. Empirical Economics, 20(2), 325-332.

Battese, G. E., \& Broca, S. S. (1997). Functional forms of stochastic frontier production functions and models for technical inefficiency effects: A comparative study for wheat farmers in Pakistan. Journal of Productivity Analysis, 8(4), 395-414.

Bauer, P. W., Berger, A. N., Ferrier, G. D., \& Humphrey, D. B. (1998). Consistency conditions for regulatory analysis of financial institutions: a comparison of frontier efficiency methods. Journal of Economics and Business, 50(2), 85-114.

Boame, A. K. (2004). The technical efficiency of Canadian urban transit systems. Transportation Research Part E: Logistics and Transportation Review, 40(5), 401-416.

Buckley, P. J., Clegg, J., Zheng, P., Siler, P. A., \& Giorgioni, G. (2010). The impact of foreign

direct investment on the productivity of China's automotive industry. In Foreign Direct Investment, China and the World Economy (pp. 284-304). Palgrave Macmillan UK.

Chang, V., \& Tovar, B. (2014). Efficiency and productivity changes for Peruvian and Chilean ports terminals: A parametric distance functions approach. Transport Policy, 31, 83-94.

Charnes, A., \& Cooper, W. W. (1962). Programming with linear fractional functionals. Naval Research Logistics Quarterly, 9(34), 181-186.
Charnes, A., Cooper, W. W., \& Rhodes, E. (1978). Measuring the efficiency of Decision Making Unit. European Journal of Operational Research, 2, 429-444.

Coelli, T. J., \& Battese, G. E. (1996). Identification of factors which influence the technical inefficiency of Indian farmers. Australian Journal of Agricultural Economics, 40(2), 103-128.

Coelli, T. J., Rao, D. S. Prasada \& Battese, G. E. (1998). An introduction to efficiency and productivity analysis. Boston: Kluwer Academic Publisher.

Coelli, T., \& Perelman, S. (1999). A comparison of parametric and non-parametric distance functions: With application to European railways. European Journal of Operational Research, 117(2), 326-339.

Coelli, T. J., Rao, D. S. P., O’Donnell, C. J., $\&$ Battese, G. E. (2005). An introduction to efficiency and productivity analysis. Springer Science \& Business Media.

Cooper, W. W., Seiford, L. M., \& Tone, K. (2000). Data Envelopment Analysis. A comprehensive text with models, applications, references and DEA-Solver Software. Boston: Kluwer Academic Publishers.

Cooper, W. W., Seiford, L. M., \& Tone, K. (2007). The basic CCR model. In Data envelopment analysis a comprehensive text with models, applications, references and DEA-Solver software. (2nd ed.). New York: Springer Science Business Media, Inc.

Coto-Millán, P., Inglada, V., Legidos, B. R., \& Rodríguez-Álvarez, A. (2004). Changes in the world air industry: An analysis of technical efficiency. International Journal of Transport Economics, 341-354.

Cullinane, K., Wang, T. F., Song, D. W., \& Ji, P. (2006). The technical efficiency of container ports: comparing data envelopment analysis and stochastic frontier analysis. Transportation Research Part A: Policy and Practice, 40(4), 354-374. 
Fahmy-Abdullah, M., Ismail, R., Sulaiman, N. \& Talib, B. A. (2017). Technical efficiency in Transport Manufacturing Firms: Evidence from Malaysia, Asian Academy of Management Journal, 22(1).

Fahmy-Abdullah, M., Sieng, L. W., \& Isa, H. M. (2019). Technical efficiency evaluation: Study on Malaysian Electrical and Electronics Firms. Asian Academy of Management Journal, 24(2), 1-19.

Fahmy-Abdullah, M., L.W. Sieng, \& S. Ridzuan. Data Envelopment Analysis (DEA) two stages in identify determinant factor of efficiency techniques for transport in manufacturing firms. Sains Malaysiana, 48(4), 901-8.

Farrell, M. J. (1957). The measurement of productive efficiency. Journal of the Royal Statistical Society. Series A (General), 120(3), 253-290.

Ferrier, G. D., \& Lovell, C. K. (1990). Measuring cost efficiency in banking: Econometric and linear programming evidence. Journal of Econometrics, 46(1-2), 229-245.

Fiorentino, E., Karmann, A., \& Koetter, M. (2006). The cost efficiency of German banks: A comparison of SFA and DEA.

Gonzalez, E., Carcaba, A., \& Ventura, J. (2015). How car dealers adjust prices to reach the product efficiency frontier in the Spanish automobile market. Omega, 51, 38-48.

Jarboui, S., Forget, P., \& Boujelbene, Y. (2012). Public road transport efficiency: A literature review via the classification scheme. Public Transport, 4(2), 101-128.

Jarboui, S. A. M. I., Pascal, F., \& Younes, B. (2013). Public road transport efficiency: A stochastic frontier analysis. Journal of Transportation Systems Engineering and Information Technology, 13(5), 64-71.

Jarboui, S., Forget, P., \& Boujelben, Y. (2015). Efficiency evaluation in public road transport: a stochastic frontier analysis. Transport, 30(1), 1-14.
Karlaftis, M. G., \& Tsamboulas, D. (2012). Efficiency measurement in public transport: Are findings specification sensitive? Transportation Research Part A: Policy and Practice, 46(2), 392-402.

Latif, M. S. A., Fahmy-Abdullah, M., \& Sieng, L. W. (2019). Determinants factor of technical efficiency in machinery manufacturing industry in Malaysia. International Journal of Supply Chain Management, 8(6), 917928.

Lin, Z., Choo, Y., \& Oum, T. H. (2013). Efficiency benchmarking of North American airports: Comparative results of productivity index, data envelopment analysis and stochastic frontier analysis. In Journal of the Transportation Research Forum 52(1), 4767. Transportation Research Forum.

Lovell, C. A. K. (1993). Production frontiers and productive efficiency. In $\mathrm{H}$. Fried, CAK Lovell \& H. Schmidt (Eds.) The measurement of productive efficiency.

Mahadevan, R. (2004). The economics of productivity in Asia and Australia. Edward Elgar Publishing.

Mankiw, N. G., Phelps, E. S., \& Romer, P. M. (1995). The growth of nations. Brookings Papers on Economic Activity, 1995(1), 275326.

Mazumder, R., \& Adhikary, M. (2010). Measuring technical efficiency in the Indian automobile industry. South Asia Economic Journal, 11(1), 53-67.

Meeusen, W., \& Van den Broeck, J. (1977). Efficiency estimation from Cobb-Douglas production functions with composed error. International Economic Review, 435-444.

MITI (2013). National Automotive Policy 2014. Ministry of International Trade and Industry.

Noor Aini., A. K. (2013). Ownership and technical efficiency in Malaysia's automotive industry: A stochastic frontier production function analysis. The Journal of International Trade \& Economic Development, 22(4), 509-535. 
Nunamaker, T. R. (1985). Using data envelopment analysis to measure the efficiency of non profit organizations: A critical evaluation. Managerial and Decision Economics, 6(1), 50-58.

Odeck, J., \& Brathen, S. (2012). A meta-analysis of DEA and SFA studies of the technical efficiency of seaports: A comparison of fixed and random-effects regression models. Transportation Research Part A: Policy and Practice, 46(10), 1574-1585.

Perbadanan Produktiviti Malaysia. (2012/2013). Laporan Produktiviti 2013 dan 2014. Kuala Lumpur: Perbadanan Produktiviti Malaysia.

Putri., Z. A. (2007). Kajian mengenai perbezaan produktiviti antara syarikat asing dan syarikat tempatan dalam industri automotif di Malaysia. (Tesis Ijazah Sarjana). Universiti Kebangsaan Malaysia.

Rahmah, I., \& Idris, J. (2008). Analisis perubahan kecekapan teknikal, perubahan teknologi, pertumbuhan produktiviti faktor keseluruhan dan pertumbuhan output dalam industri peralatan pengangkutan di Malaysia. Sains Humanika, 49(1).

Randrianarisoa, L. M., Bolduc, D., Choo, Y. Y., Oum, T. H., \& Yan, J. (2015). Effects of corruption on efficiency of the European airports. Transportation Research Part A: Policy and Practice, 79, 65-83.
Rhee, M., \& Kim, T. (2015). The role of experience in a governmental regulatory investigation in the US automobile industry: Organizational learning versus reputational dynamics. Socio-Economic Review, 13(2), 285-308.

Sabli, M.A.N., Fahmy-Abdullah, M., \& L.W. Sieng. Application of Two-Stage Data Envelopment Analysis (DEA) in identifying the technical efficiency and determinants in the plastic manufacturing industry in Malaysia. International Journal of Supply Chain Management, 8(6), 899-907.

Sun, X., Lv, X., \& Li, L. (2015). Sufficient and comprehensive measurement of Automobile Manufacturing Industry Performance Applying Bi-objective Superefficiency DEA.

Tingley, D., Pascoe, S., \& Coglan, L. (2005). Factors affecting technical efficiency in fisheries: Stochastic production frontier versus data envelopment analysis approaches. Fisheries Research, 73(3), 363-376.

Yu, M. M., \& Fan, C. K. (2009). Measuring the performance of multimode bus transit: A mixed structure network DEA model. Transportation Research Part E: Logistics and Transportation Review, 45(3), 501-515. 